\title{
Formulation and Physical Evaluation of Edible Film Dosage from Ethanol Extract of Betel Leaves (Piper betle L) for Canker Sore Drugs
}

\author{
Yenni P. Tanjung ${ }^{1 *}$, Andi I. Julianti², Aghnia W. Rizkiyani ${ }^{1}$ \\ ${ }^{1}$ Departement of Pharmaceutical Technology, Bumi Siliwangi Academy of Pharmacy, Bandung, Indonesia \\ 2 2Departement of Pharmacology, Bumi Siliwangi Academy of Pharmacy, Bandung, Indonesia
}

Submitted 24 August 2020; Revised 18 October 2020; Accepted 21 October 2020; Published 05 February 2021

*Corresponding author: yennipuspitatanjung85@gmail.com

\begin{abstract}
Canker sore which in medical terms is called aphthous stomatitis is a wound in the mouth that can cause pain and discomfort. Piper betel leaf can be used for strengthening the teeth, cure canker sores, treat the bad breath and stop the gum from bleeding. The research aimed to determine the edible film formula of betel leaf ethanol extract that met the physical evaluation requirements and to determine the effect of variation concentration of sorbitol and HPMC (Hydroxypropyl methylcellulose) on the physical evaluation. Edible film preparation from betel leaf extract is a thin layer made from the basic ingredients of corn starch, sorbitol, and HPMC. In this research, 3 edible film formulas were made with variations in the concentration of sorbitol and HPMC, namely: F1 (5\%;5\%), F2 (4\%;4\%), F3 (3\%;3\%). Data of evaluation results were analyzed statistics by Kruskal wallis method. The results showed that F1, F2 and F3 meet the physical evaluation requirements for edible film dosage. Variations in the concentration of sorbitol and HPMC gave different results significantly influence $(p<0.05)$ on weight uniformity, film thickness, solubility and dissolution time, and did not significantly influence ( $\mathrm{p}>0.05)$ on the organoleptic test, fragility of edible film, water resistance (swelling) and moisture content.
\end{abstract}

Keywords: Betel leaf extract, edible film, HPMC, canker sore, sorbitol

\section{Formulasi dan Evaluasi Fisik Sediaan Edible film dari Ekstrak Etanol Daun Sirih (Piper betle L.) Untuk Obat Sariawan}

\begin{abstract}
Abstrak
Sariawan yang dalam istilah medis disebut stomatitis aftosa adalah luka di dalam mulut yang dapat menimbulkan rasa sakit dan tidak nyaman. Daun sirih dapat digunakan untuk menguatkan gigi, menyembuhkan sariawan, menghilangkan bau mulut dan menghentikan perdarahan gusi. Tujuan penelitian ini adalah untuk mengetahui formula edible film dari ekstrak etanol daun sirih yang memenuhi syarat evaluasi fisik dan untuk mengetahui pengaruh variasi konsentrasi dari sorbitol dan HPMC terhadap hasil evaluasi fisik. Edible film dari ekstrak daun sirih merupakan potongan lapisan tipis yang dibuat dengan bahan dasar pati jagung, sorbitol, dan HPMC (Hydroxypropyl methylcellulose). Pada penelitian ini, dibuat 3 formula edible film dengan variasi konsentrasi sorbitol dan HPMC, yaitu F1 (5\%;5\%), F2 (4\%;4\%), F3 (3\%;3\%). Data hasil evaluasi dianalisis statistik menggunakan metode Kruskal Wallis. Hasil evaluasi fisik sediaan edible film ekstrak daun sirih menunjukan bahwa F1, F2 dan F3 memenuhi syarat hasil evaluasi fisik. Variasi konsentrasi sorbitol dan HPMC memberikan hasil berbeda berpengaruh secara signifikan $(p<0,05)$ terhadap keseragaman bobot, ketebalan film, daya larut dan waktu melarut, serta tidak berpengaruh secara signifikan $(p>0,05)$ terhadap uji organoleptik, kerapuhan edible film, ketahanan air (swelling) dan kadar air
\end{abstract}

Kata Kunci: Sariawan, edible film, ekstrak daun sirih, HPMC, sorbitol 


\section{Pendahuluan}

Sariawan yang dalam istilah medis disebut stomatitis aftosa (apthous stomatitis) atau canker sore merupakan penyakit mulut yang paling umum terjadi. Prevalensi ulserasi pada mulut di dunia adalah sebanyak $4 \%$, dan SAR merupakan penyakit dengan prevalensi yang terbesar yaitu $25 \%$. Sariawan adalah luka di dalam mulut yang dapat menimbulkan rasa sakit dan tidak nyaman. Sariawan dapat menyerang berbagai kalangan dan sering timbul pada mulut yang tidak berkeratin. ${ }^{1}$ Tanaman obat tradisional sebagai terapi alternatif untuk sariawan telah banyak digunakan dibanyak negara selama beberapa dekade terakhir, termasuk Indonesia yang terkenal keanekaragaman hayatinya. Sariawan dapat disembuhkan dengan terapi alternatif dengan memanfaatkan tanaman obat tradisional. ${ }^{2}$

Pemanfaatan tanaman obat tradisional di lingkungan masyarakat sebagai pengobatan alami untuk menanggulangi penyakit, secara luas telah dirasakan oleh masyarakat. Hal ini tercermin dengan semakin meningkatnya konsumen pada pengobatan alami. Krisis ekonomi yang berkepanjangan meningkatkan daya beli masyarakat terhadap obat tradisional, terutama masyarakat golongan menengah ke bawah memilih menggunakan obat tradisional dibandingkan obat kimia. Pengetahuan tentang tumbuhan obat didapatkan melalui warisan budaya bangsa secara turun temurun. ${ }^{3}$

Sirih (Piper betle L.) termasuk ke dalam family Piperaceae yang sangat berguna untuk kesehatan gigi dan mulut, sebagai obat kumur dan sariawan. Kandungan senyawa fenol pada daun sirih bersifat antimikroba yang kuat dan efektif menghambat pertumbuhan bakteri. ${ }^{4}$

Umumnya masyarakat menggunakan daun sirih sebagai obat masih dengan cara sederhana, mulai dari penggunaannya yang harus direbus dahulu, kemudian diminum sarinya. Cara penggunaan ini kurang praktis sehingga diperlukan inovasi baru untuk meningkatkan kenyaman dan kemudahan dalam penggunaan, di antaranya dibuat menjadi sediaan edible film. Pembentuk edible film yang digunakan yaitu pati jagung,
HPMC, dan sorbitol sehingga dihasilkan lapisan tipis. Pembentuk edible film tersebut digunakan juga sebagai pembawa ekstrak etanol daun sirih. ${ }^{5}$

Pada penelitian ini ekstrak etanol daun sirih dibuat dalam bentuk sediaan edible film. Tujuan dari penelitian ini adalah untuk mengetahui formula edible film dari ekstrak etanol daun sirih yang memenuhi syarat evaluasi fisik dan untuk mengetahui pengaruh variasi konsentrasi dari sorbitol dan HPMC terhadap hasil evaluasi fisik.

Pada penelitian ini dibuat sediaan edible film ekstrak etanol daun sirih yang divariasikan pada konsentrasi sorbitol dan HPMC, kemudian dilakukan evaluasi fisik dari sediaan edible film ekstrak etanol tersebut. Diduga variasi konsentrasi sorbitol dan HPMC dapat mempengaruhi hasil evaluasi fisik sediaan edible film.

\section{Metode}

2.1. Alat

Cawan penguap, beaker glass (pyrex), gelas ukur (pyrex), , timbangan digital (fujitsu), tabung reaksi (pyrex), kertas saring, pipet tetes, oven, spatel, Roche Friabilator.

\subsection{Bahan}

Ekstrak etanol daun sirih diperoleh dari Unit Produksi Lansida (Yogyakarta) dengan No. sampel 190233271 asal negara Indonesia, pati jagung, HPMC, sorbitol, Natrium sakarin, minyak permen, nipagin, nipasol, aquades.

\subsection{Prosedur}

\subsubsection{Pembuatan Edible Film Ekstrak Etanol} Daun Sirih

Prosedur pembuatan sediaan edible film ekstrak etanol daun sirih diawali pati jagung didispersikan pada suhu $\pm 60^{\circ} \mathrm{C}$ (massa 1). HPMC dibasahi menggunakan sorbitol, kemudian dikembangkan dengan air dan diaduk pada suhu $\pm 60^{\circ} \mathrm{C}$ (massa 2). Massa 1 dan massa 2 dicampur dan diaduk hingga terbentuk massa gel. Selanjutnya ditambahkan ekstrak etanol daun sirih, larutan natrium sakarin, larutan nipagin dan larutan nipasol, diaduk hingga homogen. Setelah homogen ditambahkan minyak permen dan 
diaduk hingga homogen. Sediaan disebarkan pada cetakan $(20 \times 10 \mathrm{~cm})$ untuk kemudian dikeringkan dengan oven pada suhu 40-50 ${ }^{0} \mathrm{C}$ selama 45 jam. Setelah kering, sediaan dilepaskan dari cetakan dan dipotong-potong dengan ukuran $3 \times 2 \mathrm{~cm} .{ }^{5}$

\subsubsection{Evaluasi Fisik Sediaan Edible Film}

a. Uji Organoleptik

Simplisia yang digunakan adalah herba seledri yang diperoleh dari Pasar Induk Kramat Jati, Jakarta Timur dan dideterminasi di LIPI Cibinong dengan surat determinasi no. 1777/IPH.1.01/If.07/VIII/2016.

\section{b. Uji Keseragaman Bobot}

Sepuluh edible film dipilih secara acak dan dihitung berat rata-ratanya dengan neraca analitik. Ambil satu film lalu ditimbang dan dibandingkan dengan berat rata-rata untuk mendapatkan nilai penyimpangan. ${ }^{6}$

\section{c. Uji Ketebalan Edible Film}

Pengukuran ketebalan edible film menggunakan micrometer sekrup. Nilai ketebalan yang didapat merupakan rataan dari pengukuran pada lima tempat. ${ }^{7}$

\section{d. Uji Kerapuhan Edible Film}

Dua puluh lembar edible film bebas dari debu ditimbang bersama $\left(\mathrm{W}_{1}\right)$, kemudian dimasukkan ke dalam Roche Friabilator, jalankan selama 4 menit dengan kecepatan 25 rpm. Bersihkan 20 lembar edible film tersebut dari debu dan timbang kembali $\left(\mathrm{W}_{2}\right){ }^{5}$

Kerapuhan edible film dapat dihitung dengan rumus :

$$
\% \text { Kerapuhan }=1-\mathrm{W}_{2} / \mathrm{W}_{1} \times 100 \%
$$

e. Uji Ketahanan air (swelling) edible film Pengujian dilakukan dengan cara memotong edible film dengan ukuran 1 $\mathrm{cm}$ x $1 \mathrm{~cm}$, kemudian menimbang berat awal edible film yang akan diuji (Wo), dan dimasukkan ke dalam cawan petri yang berisi aquades $15 \mathrm{ml}$ selama 10 menit. Edible film yang telah direndam kemudian diangkat dan air yang terdapat pada permukaan edible film dihilangkan dengan tisu kertas, setelah itu dilakukan penimbangan berat akhir edible film (W). ${ }^{8}$ Sehingga diperoleh presentase air yang diserap dengan menggunakan persamaan berikut :

\section{Air yang diserap $(\%)=\left(\mathrm{W}-\mathrm{W}_{0}\right) / \mathrm{W} \times 100 \%$}

f. Uji Daya dan Waktu Melarut

Edible film ditempatkan pada cawan petri, kemudian diisi dengan dapar fosfat $\mathrm{pH}$ 6,8. Banyaknya pelarut yang digunakan untuk melarutkan film tercatat sebagai daya melarut. Waktu yang dibutuhkan untuk melarut seluruhnya dicatat sebagai waktu

Tabel 1. Formula Edible Film Ekstrak Etanol Daun Sirih

\begin{tabular}{cccc}
\hline Bahan & & Formula (\%) & F2 \\
\cline { 2 - 4 } Ekstrak etanol daun sirih & F1 & 10 & 10 \\
Pati jagung & 10 & 2 & 2 \\
HPMC & 2 & 4 & 3 \\
Sorbitol & 5 & 0,2 & 3 \\
Na. Sakarin & 5 & 1 & 0,2 \\
Minyak permen & 0,2 & 0,18 & 0,18 \\
Nipagin & 1 & 0,04 & 0,04 \\
Nipasol & 0,18 & 100 & 100 \\
Aquades hingga & 0,04 & 100 & 4 \\
\hline
\end{tabular}

Keterangan: F1: Formula Sorbitol:HPMC (5\%:5\%)

F2: Formula Sorbitol:HPMC (4\%:4\%)

F3: Formula Sorbitol:HPMC (3\%:3\%) 
melarut. ${ }^{3}$

\section{g. Uji Kadar air}

Edible film sebanyak $2 \mathrm{~g}$ dan diletakkan dalam wadah yang sudah diketahui beratnya, kemudian, dikeringkan dalan oven pada suhu $105^{\circ} \mathrm{C}$ selama 3 jam. Kemudian, didinginkan dalam desikator selama 15 menit dan ditimbang. Perlakuan tersebut ditimbang sampai diperoleh selisih berat konstan sebesar $\pm 0,2$ gram. ${ }^{3}$

\subsubsection{Analisis Data Statistik}

Hasil data pengamatan evaluasi fisik sediaan edible film dari ekstrak etanol daun sirih dalam penelitian ini akan dianalisis secara statistik menggunakan metode Kruskal Wallis.

\section{Hasil}

3.1. Hasil Evaluasi Fisik

Pada penelitian ini dilakukan formulasi sediaan edible film ekstrak etanol daun sirih yang divariasikan pada konsentrasi sorbitol dan HPMC. Setelah dilakukan formulasi, selanjutnya sediaan edible film tersebut dilakukan evaluasi fisik yang terdiri dari organoleptis, keseragaman bobot, ketebalan film, kerapuhan edible film, ketahanan air (swelling) edible film, daya dan waktu melarut, serta kadar air. Hasil evaluasi fisik sediaan edible film dapat dilihat pada tabel 2.

Berdasarkan tabel 2 dapat diketahui bahwa F1, F2, dan F3 memiliki organoleptis yang sama yaitu berbentuk lembaran tipis warna coklat dengan bintik-bintik hitam dengan bau khas sirih dan mint. Hasil evaluasi keseragaman bobot.dari ketiga formula memenuhi syarat yaitu berada pada rentang 102-138 mg.3 Syarat ketebalan film yang baik dari sediaan edible film adalah 0,1-0,5 mm, dan dari tabel 2 dapat dilihat bahwa ketiga formula memenuhi syarat yang ditentukan. ${ }^{9}$ Pada pengujian kerapuhan edible film, ketiga formula mengalami penurunan bobot akibat gesekan tetapi tidak patah dan bentuknya tetap

Tabel 2. Hasil Penapisan Fitokimia dan Pengujian Kadar Apigenin Ekstrak Etanol 50\% Herba Seledri (Apium graveolen $\mathrm{L}$.)

\begin{tabular}{|c|c|c|c|}
\hline \multirow{2}{*}{ Jenis Evaluasi Fisik } & \multicolumn{3}{|c|}{ Formula } \\
\hline & $\mathrm{F} 1$ & $\mathrm{~F} 2$ & $\mathrm{~F} 3$ \\
\hline \multicolumn{4}{|l|}{ Organoleptis } \\
\hline Bentuk & Lembaran Tipis & Lembaran Tipis & Lembaran Tipis \\
\hline Warna & Coklat Bintik Hitam & Coklat Bintik Hitam & Coklat Bintik Hitam \\
\hline Bau & Khas Sirih dan Mint & Khas Sirih dan Mint & Khas Sirih dan mint \\
\hline \multicolumn{4}{|l|}{ Keseragaman Bobot } \\
\hline Bobot Rata-rata (mg) & 121,2 & 110,3 & 102,2 \\
\hline \multicolumn{4}{|l|}{ Ketebalan film } \\
\hline Ketebalan Rata-rata (mm) & 0,22 & 0,20 & 0,17 \\
\hline \multicolumn{4}{|l|}{ Kerapuhan Edible film } \\
\hline Nilai Kerapuhan (\%) & 0,876 & 0,640 & 0,302 \\
\hline \multicolumn{4}{|c|}{ Ketahanan Air (Swelling) Edible film } \\
\hline Ketahanan Air Rata-rata (\%) & 78,73 & 68,85 & 61,04 \\
\hline \multicolumn{4}{|l|}{ Daya dan Waktu Melarut } \\
\hline Daya Larut $(\mathrm{mL})$ & 2,7 & 2 & 1,3 \\
\hline Waktu Melarut (detik) & 20,52 & 16,60 & 13,54 \\
\hline \multicolumn{4}{|l|}{ Kadar Air } \\
\hline Nilai Kadar Air (\%) & 14,06 & 10,31 & 8,44 \\
\hline $\begin{aligned} \text { terangan: F1: Formula Sorbito } \\
\text { F2: Formula Sorbito } \\
\text { F3: Formula Sorbito }\end{aligned}$ & $\begin{array}{l}5 \%: 5 \%) \\
4 \%: 4 \%) \\
3 \%: 3 \%)\end{array}$ & & \\
\hline
\end{tabular}


utuh. ${ }^{5}$ Pengujian Ketahanan air (swelling) pada sediaan edible film ekstrak etanol daun sirih paling tinggi dimiliki oleh F1. Evaluasi fisik terhadap daya larut pada ketiga formula memenuhi syarat yaitu berada pada rentang 0,3-3 mL. ${ }^{3}$ Evaluasi waktu larut pada ketiga formula juga memenuhi syarat yaitu berada pada rentang 5-30 detik. $^{7}$ Pada pengujian kadar air dari ketiga formula menunjukkan hasil yang memenuhi syarat yaitu kurang dari $20 \% .^{3}$

\subsection{Hasil Analisis Statistik}

Berdasarkan hasil analisis menggunakan metode Kruskal Wallis menunjukan bahwa variasi konsentrasi sorbitol dan HPMC, memberikan hasil berbeda berpengaruh secara signifikan terhadap hasil evaluasi fisik sediaan edible film dari ekstrak daun sirih yang meliputi keseragaman bobot, ketebalan film, daya larut, dan waktu larut. Serta tidak berpengaruh signifikan terhadap uji organoleptis, kerapuhan edible film, ketahanan air (swelling), dan kadar air.

\section{Pembahasan}

Dalam penelitian ini, dibuat 3 formula edible film dengan variasi konsentrasi sorbitol dan HPMC. Hal ini dilakukan untuk mengetahui pengaruh variasi konsentrasi sorbitol dan HPMC pada formula edible film. Ekstrak daun sirih dengan konsentrasi 10\% dapat mengobati sariawan dan diformulasikan menjadi sediaan edible film dengan penambahan beberapa bahan tambahan. Pati jagung dan HPMC berfungsi sebagai polimer yang larut dalam air (hidrokoloid). Hidrokoloid berfungsi untuk membentuk struktur film agar tidak mudah hancur. Pati jagung dan HPMC yang masing-masing sudah terdispersi kemudian diaduk hingga terbentuk gel jernih pada suhu $\pm 60^{\circ} \mathrm{C} .^{5}$ Pemanasan suhu $\pm 60^{\circ} \mathrm{C}$ bertujuan untuk mencapai suhu gelatinisasi pati, sehingga pati dapat tergelatinisasi sempurna dan diperoleh film yang homogen. Apabila tanpa adanya pemanasan, dapat terjalin interaksi intermolekuler sangat kecil, sehingga pada saat dikeringkan film akan menjadi retak. HPMC dibasahi dengan sorbitol dimana sorbitol berfungsi sebagai plasticizer. Plasticizer berfungsi untuk meningkatkan elastisitas dari film dengan mengurangi derajat ikatan hidrogen dan meningkatkan jarak antar molekul dari polimer. Penggunaan plasticizer yang terlampau banyak akan meningkatkan permeabilitas terhadap uap air. ${ }^{10}$ Selain bahan-bahan tersebut juga ditambahkan bahan lainnya yaitu minyak permen sebagai pemberi aroma mint. Natrium sakarin yang berfungsi sebagai pemanis buatan. Nipagin dan nipasol yang berfungsi sebagai pengawet sediaan, masing-masing dilarutkan dalam air panas secukupnya dan ditambahkan ke dalam massa gel pada suhu kamar. Penggunaan nipagin dan nipasol yang dikombinasi bertujuan untuk meningkatkan efek terhadap bakteri dan jamur. Selanjutnya sediaan diaduk hingga homogen dan disebarkan pada cetakan $(20 \times 10 \mathrm{~cm})$ dan dikeringkan dalam oven dengan suhu $40-45^{\circ} \mathrm{C}$ selama 45 jam, lalu dilepas dari cetakan dan dipotong-potong dengan ukuran $3 \times 2 \mathrm{~cm} .5$

\subsection{Hasil Uji Organoleptis}

Pada pemeriksaan organoleptik bertujuan untuk mengamati keadaan sediaan secara visual. Pengamatan dilakukan terhadap bentuk, bau, dan warna dari sediaan edible film. Pada formula F1, F2, dan F3 memiliki organoleptis yang sama yaitu berbentuk lembaran tipis warna coklat dengan bintikbintik hitam dengan bau khas sirih dan mint.

\subsection{Hasil Uji Keseragaman Bobot}

Uji keseragaman bobot merupakan suatu uji yang dilakukan untuk melihat keseragaman bobot pada edible film dengan cara menimbang 10 lembar edible film secara seksama. Hasil evaluasi keseragaman bobot dari F1, F2 dan F3 memenuhi syarat yaitu berada pada rentang 102-138 mg. Penambahan konsentrasi sorbitol dan HPMC berpengaruh nyata terhadap bobot edible film. Semakin tinggi nilai konsentrasi sorbitol dan HPMC maka semakin tinggi bobot edible film. ${ }^{6}$

\subsection{Hasil Uji Ketebalan Film}

Pemeriksaan ketebalan edible film 


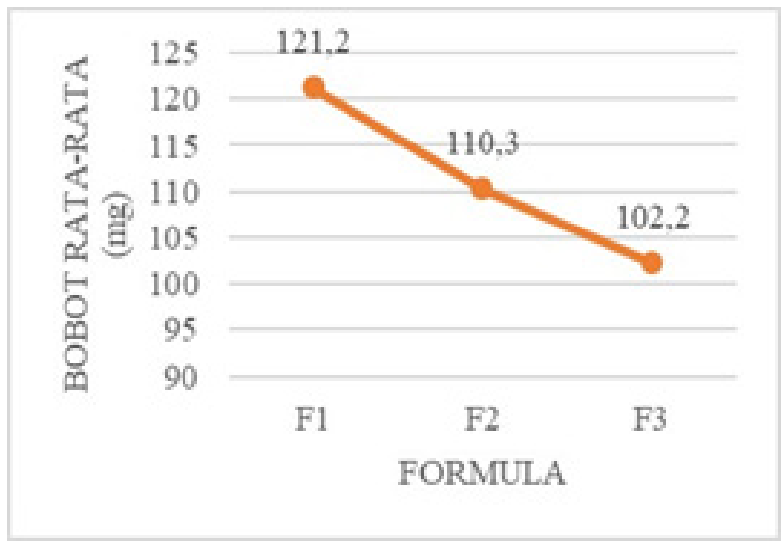

Gambar 1. Hasil Uji Bobot Rata-Rata

bertujuan untuk mengukur seberapa tebal sediaan edible film dengan cara menggunakan mikrometer dengan ketelitian 0,01 $\mathrm{mm}$. Standar ketebalan edible film yaitu maksimal 0,1-0,5 mm. ${ }^{10}$ Formula F1, F2, dan F3 memenuhi syarat ketebalan edible film. Pada hasil penelitian dapat dilihat bahwa variasi konsentrasi sorbitol sebagai plasticizer mempengaruhi ketebalan film. Hal ini sesuai dengan penelitian yang dilakukan oleh Sitompul dkk (2017) bahwa efek plasticizer mempengaruhi secara signifikan terhadap ketebalan film. Selain itu pati jagung dan HPMC dapat dijelaskan melalui fungsi keduanya sebagai thickening agent dalam sediaan farmasi. ${ }^{11}$

\subsection{Daya dan Waktu Melarut}

Pengujian daya dan waktu melarut bertujuan untuk menunjukkan integritas film dalam lingkungan cair. Persyaratan daya larut sediaan edible film adalah $0,3-3 \mathrm{ml} .^{3}$
Persyaratan waktu melarut sediaan edible film adalah 5 - 30 detik. $^{12}$ Berdasarkan tabel 2 dapat diketahui bahwa F1, F2 dam F3 memenuhi syarat daya larut dan waktu larut. Kelarutan edible film dalam air ditentukan oleh komposisi bahan dalam pembetuk edible film. Hal ini dapat disimpulkan bahwa semakin besar penambahan plasticizer yaitu sorbitol maka akan menghasilkan kelarutan edible film dalam air yang semakin besar. ${ }^{13}$ Hal ini sesuai dengan pernyataan Ballesteros dkk (2020) bahwa semakin tinggi konsentrasi penggunaan plasticizer yang bersifat hidrofilik seperti sorbitol maka akan meningkatkan kelarutan edible film dalam air. ${ }^{14}$

\subsection{Hasil Uji Ketahanan Air (Swelling) Edible Film}

Uji ketahanan air dilakukan untuk mengetahui ketahanan suatu sediaan edible film terhadap air. ${ }^{12}$ Berdasarkan tabel 2 dapat diketahui bahwa hasil uji ketahanan air

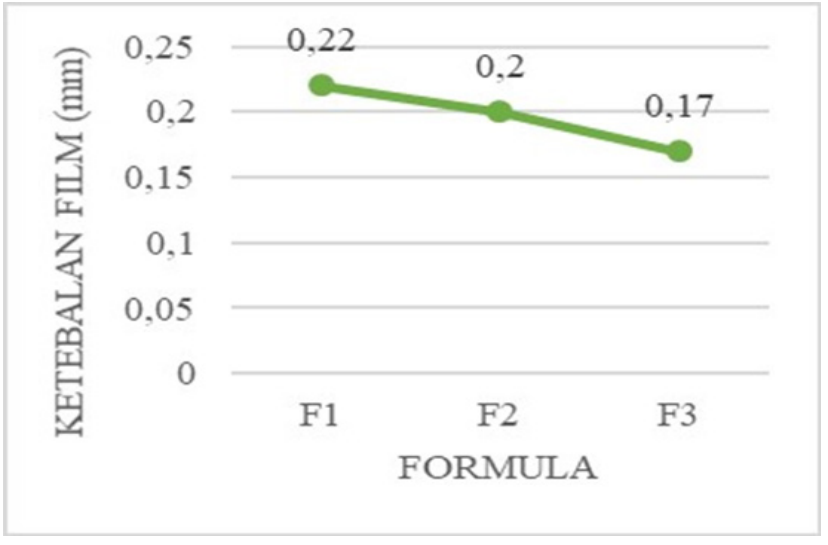

Gambar 2. Hasil Uji Ketebalan Film 


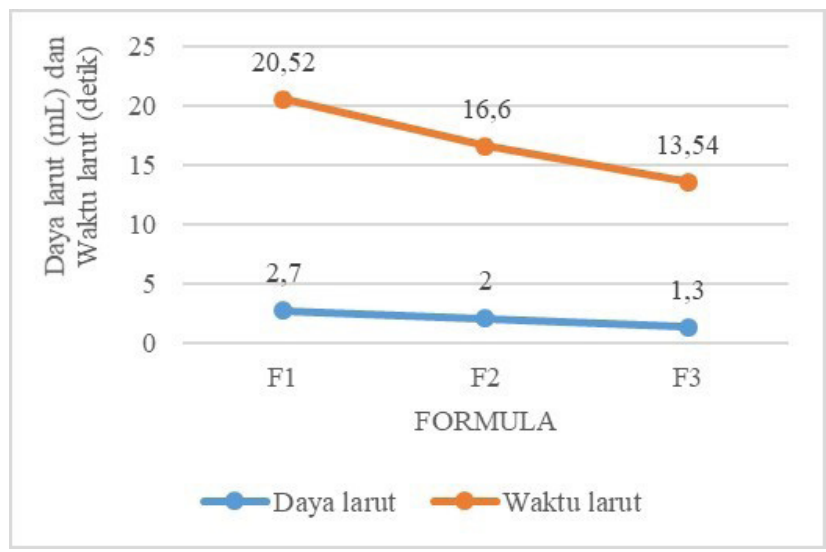

Gambar 3. Hasil Uji Daya dan Waktu Larut

tertinggi terjadi pada $\mathrm{F} 1$ dengan persentase $78,73 \%$ dan yang terendah terjadi pada F3 dengan persentase $61,04 \%$. Semakin besar konsentrasi sorbitol maka nilai ketahanan airnya semakin besar. Sorbitol merupakan plasticizer yang bersifat hidrofilik sehingga mempunyai kemampuan dalam penyerapan air. ${ }^{14}$ Hal ini sesuai dengan yang penelitian yang dilakukan oleh Sitompul (2017) bahwa daya serap uap air edible film akan meningkat seiring dengan meningkatnya konsentrasi plasticizer yang ditambahkan. Peningkatan ini terjadi karena sifat dari plasticizer yang rata-rata bersifat higroskopis sehingga dengan bertambahnya konsentrasi plasticizer maka akan meningkatkan sifat higroskopis dan membuat daya serap uap air menjadi semakin tinggi. ${ }^{15}$

\subsection{Hasil Uji Kerapuhan Edible Film}

Pemeriksaan kerapuhan edible film adalah pemeriksaan yang dilakukan untuk menentukan atau mengukur kekuatan fisik sediaan film terhadap gesekan. Berdasarkan hasil uji kerapuhan film, F3 memiliki nilai kerapuhan lebih rendah dibandingkan dengan F1 dan F2. Semakin tinggi konsentrasi HPMC maka akan semakin kuat edible film. Hal ini berarti dengan penambahan HPMC tersebut memberikan pengaruh terhadap kerapuhan edible film. Pada uji kerapuhan ini semua formula edible film yang diuji tidak patah dan bentuknya tetap utuh, tetapi hanya mengalami pengurangan berat karena gesekan yang terjadi ketika diuji kerapuhannya. ${ }^{5}$

\subsection{Kadar Air}

Pengujian kadar air adalah uji yang dilakukan untuk menentukan kadar kandungan air yang terdapat dalam suatu sediaan edible film. Persyaratan kadar air yaitu dibawah 20\%. ${ }^{3}$ Berdasarkan tabel 2, didapatkan hasil formula F1, F2, dan F3 memenuhi syarat kadar air edible film.

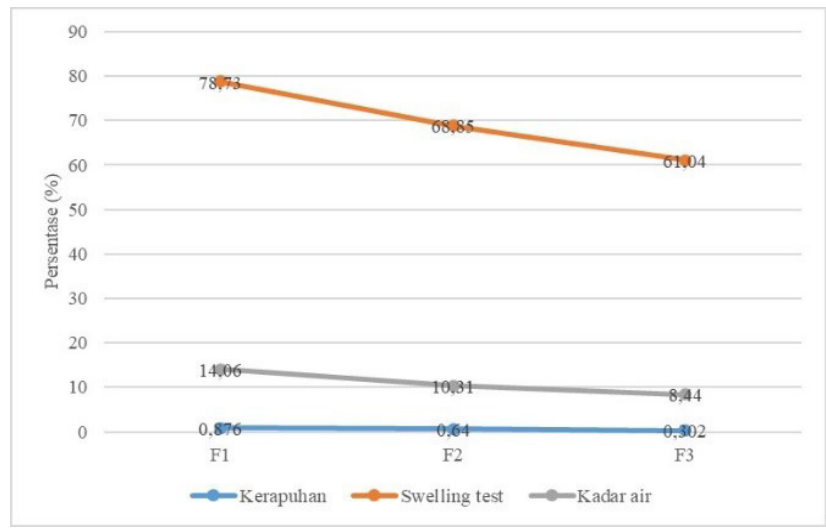

Gambar 4. Hasil Uji Ketahanan air, Kerapuhan film, dan Kadar Air 
Sesuai dengan pernyataan Sitompul dkk (2017) bahwa kadar air edible film yang dihasilkan mengalami peningkatan seiring dengan peningkatan jumlah sorbitol sebagai plasticizer. Peningkatan kadar air tersebut dikarenakan sorbitol selain berfungsi sebagai plasticizer juga berfungsi sebagai humektan, yaitu zat aditif yang bersifat higroskopis dan berfungsi untuk menjaga kandungan air pada suatu bahan. ${ }^{15}$

\section{Simpulan}

Hasil evaluasi fisik sediaan edible film ekstrak daun sirih menunjukan bahwa F1, F2 dan F3 memenuhi syarat hasil evaluasi fisik. Variasi konsentrasi sorbitol dan HPMC memberikan hasil berbeda berpengaruh secara signifikan $(p<0,05)$ terhadap keseragaman bobot, ketebalan film, daya larut dan waktu melarut, serta tidak berpengaruh secara signifikan $(p>0,05)$ terhadap uji organoleptik, kerapuhan edible film, ketahanan air (swelling) dan kadar air

\section{Daftar Pustaka}

1. Amtha R, Marcia M, Aninda AI. Plester sariawan efektif dalam mempercepat penyembuhan stomatitis aftosa rekuren dan ulkus traumatikus. Maj Kedokt Gigi Indones. 2017;3(2):69.

2. World Health Organization (WHO). WHO Traditional Medicine Strategy 2014-2023. World Heal Organ [Internet]. 2013;1-76. Available from: http://apps. who.int/iris/bitstream/10665/92455/1/97 8924150609O_eng.pdf?Ua $=1$

3. Sari DI, Fitriana Mi, Mulyadi RR, Hidayati L. Karakteristik dan uji stabilitas fisik sediaan edible film ekstrak etanol kulit batang kasturi (Mangifera casturi kosterm) berbasis gelatin. Pros Semin Kefarmasian dan Present Ilm. 2017;8-17

4. Sundari D, Almasyhuri A. Uji Aktivitas Antiseptik Ekstrak Etanol Daun Sirih (Piper betle Linn.) Dalam Obat Kumur terhadap Staphylococcus aureus secara in Vitro. J Kefarmasian Indones. 2019;9(1):10-8

5. Harmely F, Deviarny C, Yenni WS. Formulasi dan Evaluasi Sediaan Edible
Film dari Ekstrak Daun Kemangi (Ocimum americanum L.) Sebagai Penyegar Mulut. J Sains Farm Klin. 2015;1(1):38.

6. Dewi, Mulya Arsita dan Dadang Mulya. Formulasi Dan Evaluasi Sifat Fisik Serta Uji Stabilitas Sediaan Edible Film Ekstrak Etanol 96 \% Seledri (Apium graveolens L) Sebagai Penyegar Mulut Formulation and Evaluation of Physical Properties and Stability Test of Edible Film Oral dissolving film . 2019;4(2):32-40.

7. Santoso B, Pitayati PA, Pambayun R. Pemanfaatan Karaginan dan Gum Arabic Sebagai Edible Film Berbasis Hidrokoloid. 2013;33(2):140-5.

8. Rahmawati P, Ni'Maturrohmah D, Sari PL, Sari PP, Sari TNI, Suryanti V. Preparation and properties of arenga starch-chitosan based edible film. IOP Conf Ser Mater Sci Eng. 2016;107(1).

9. Nofiandi D, Rahayu N, Putri N. Formulasi dan karakterisasi edible film dari poliblend pati umbi talas kimpul-polivinil alkohol dengan. 2019;9(2):183-91.

10. Murni W, Pawignyo H, Widyawati D, Sari N. Prosiding Seminar Nasional Teknik Kimia "Kejuangan" Pembuatan Edible Film dari Tepung Jagung (Zea Mays L.) Dan Kitosan. 2013;1-9.

11. Santoso B, Priyanto G. Karakteristik Edible Film dengan Penambahan Filtrat Gambir (Uncaria gambir Roxb ) dan Filtrat Daun Pepaya ( Carica papaya L .) Characteristics of Edible Film with Addition of the Gambir Filtrate ( Uncaria gambir Roxb ) and Papaya Leaf Filtrate ( Carica p. 2019;978-9.

12. Patil P, Shrivastava SK. Fast Dissolving Oral Films : a Novel Drug Delivery System. Int J Sci Res. 2014;3(7):208893.

13. Rusli A, Metusalach M, Tahir MM. Characterization of Carrageenan Edible films Plasticized with Glycerol. J Pengolah Has Perikan Indones. 2017;20(2):219.

14. Ballesteros-Mártinez L, Pérez-Cervera C, Andrade-Pizarro R. Effect of glycerol and sorbitol concentrations on mechanical, optical, and barrier properties of sweet 
potato starch film. NFS J [Internet]. 2020;20(June):1-9. Available from: https://doi.org/10.1016/j.nfs.2020.06.002

15. Sitompul AJWS, Zubaidah E. Pengaruh jenis dan konsentrasi plasticizer terhadap sifat fisik edible film kolang kaling (Arenga pinnata). J Pangan dan Agroindustri. 2017;5(1):13-25 